\title{
Examination on Classification of EVs and Energy Management Strategies of HEV
}

\author{
Karkuzhali S, Usha Rani P
}

\begin{abstract}
In recent days, the demand for petroleum and emission of pollutant gases continuously increase. This necessitates the electrification power train which replaces Internal Combustion Engine (ICE). Despite pure electric vehicles or Battery Electric Vehicle (EV) reduce the greenhouse gas emissions, there are some major hurdles for $\mathrm{EVs}$ to overcome before they totally relieve ICE vehicles form transport sector such as range anxiety, battery storage, economic fall down due to automobile industries, etc. This necessitates Hybrid Electric vehicle (HEV) which combines two different power sources to propel the vehicle. One of the challenges in $\mathrm{HEV}$ is how to control the power coming from the two different sources such as battery and ICE. The prime goal of an Energy Management Strategy (EMS) is to manage energy flow such that fuel consumption and emissions are minimized without affecting the vehicle's performance. In this paper, the different structures of power train and energy management strategies are analysed.
\end{abstract}

Keywords: Hybrid Electric Vehicle (HEV), Energy Management Strategy (EMS), State of Charge (SOC).

\section{INTRODUCTION}

Now a days, due to increase in demand for nonrenewable fuel which are finite source, there is an increase in fuel price. Burning of fossil fuels, particularly for the power and transportation sectors are most responsible for air pollution, legislations in most of the countries are pushing for lower emissions. This necessitates electrification of power train in automobiles. But it is not possible to entirely electrify automobiles which will lead to economic fall down in the automobile industries and practical constraints such as long driving range and quick refuelling expected by consumer calls for hybrid electric vehicle (HEV). This paper is presented to provide an outline about the recent progress on electric vehicles and various energy management strategies which plays major role to lessen the fuel emission and to provide optimal power split between battery and fuel engine without compromising in vehicle's performance in HEV. This paper is organized as follows section II deals with classification of electric vehicles. Section III focuses on different architectures of HEV and Section IV deals with existing energy management strategies for HEV and plug-in hybrid electric vehicle (PHEV).Section V presents comparison of fuel consumption using various EMS.

Revised Manuscript Received on November 27, 2019

* Correspondence Author

Karkuzhali S, EEE Department, R.M.D. Engineering College, Chennai, India. Email: karkuzhali.subramani@gmail.com

Dr.P.Usha Rani, Senior member IEEE, EEE Department, R.M.D Engineering College, Chennai, India. Email: pusharani71@yahoo.com

\section{CLASSIFICATION OF ELECTRIC VEHICLES}

According to the trade off between the customer satisfaction in terms of long range drivability and less emissions forced by government legislations, there can be different types of electric vehicles such as

- Battery Electric Vehicle (BEV)

- Hybrid Electric Vehicle (HEV)

- Fuel Cell Electric Vehicle (FCEV)

- Plug in Hybrid Electric Vehicle (PHEV)

\section{DIFFERENT ARCHTECTURES OF HEV}

Vehicles which are powered by at least two sources, usually combining an internal combustion engine (ICE) and an electric motor (EM) is referred as Hybrid Electric Vehicle (HEV) [3]. Based on this, architectures of HEVs are classified as
1. Series HEV
2. Parallel HEV
3. Series-parallel HEV
4. Complex HEV

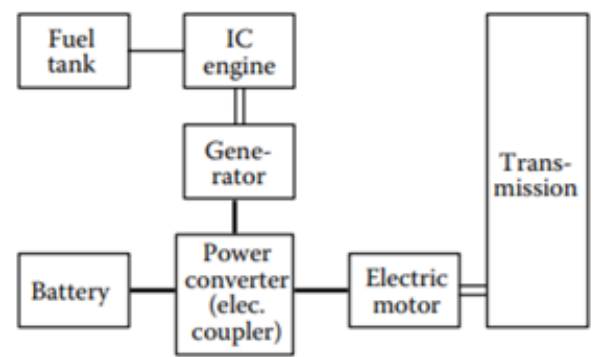

Fig.1. Series HEV [4]

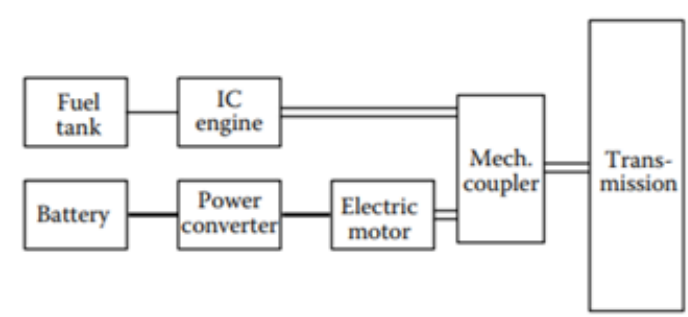

Fig.2. Parallel HEV [4] 


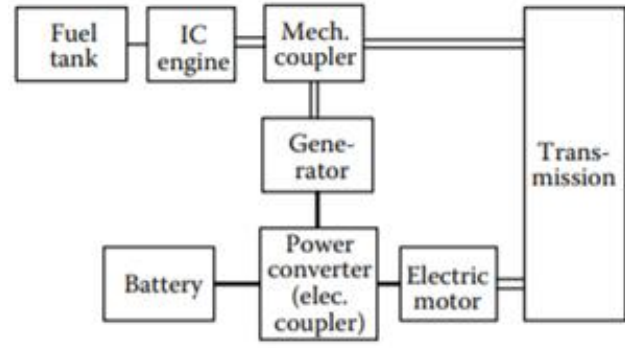

Fig.3. Series-parallel HEV [4]

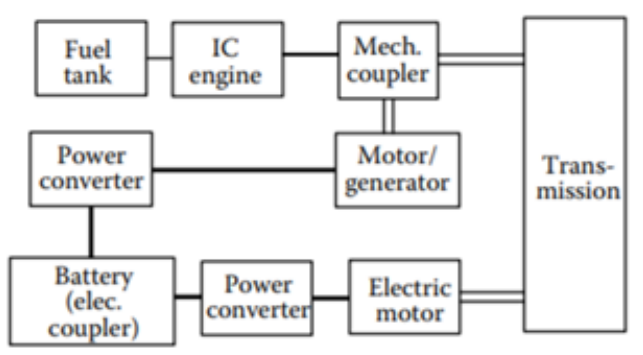

Fig.4. Complex HEV [4]

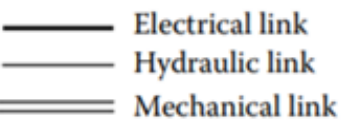

Table -I: Comparison of different types of electric vehicles. Data obtained from [1-2].

\begin{tabular}{|c|c|c|c|c|}
\hline $\begin{array}{l}\text { Type of } \\
\text { EV }\end{array}$ & $\begin{array}{c}\text { Driving } \\
\text { Component }\end{array}$ & Energy Source & Features & Challenges \\
\hline BEV & $\begin{array}{l}\text { 1.Electric } \\
\text { motor }\end{array}$ & $\begin{array}{l}\text { 1.Battery } \\
\text { 2.Ultracapacitor }\end{array}$ & $\begin{array}{l}\text { 1.No emission } \\
\text { 2. Not dependent on oil } \\
\text { 3.Type of the battery decides } \\
\text { range. } \\
\text { 4.Available commercially }\end{array}$ & $\begin{array}{l}\text { 1.Cost and capacity of the } \\
\text { battery } \\
\text { 2.Range } \\
\text { 3.Time required to charge. } \\
\text { 4.Availability of charging } \\
\text { stations } \\
\text { 5.High price }\end{array}$ \\
\hline HEV & $\begin{array}{l}\text { 1.Electric } \\
\text { motor } \\
\text { 2.ICE }\end{array}$ & $\begin{array}{l}\text { 1.Battery } \\
\text { 2.Ultracapacitor } \\
\text { 3.ICE }\end{array}$ & $\begin{array}{l}\text { 1. Very little emission } \\
\text { 2. Long range } \\
\text { 3.Power obtained from both } \\
\text { electric supply and fuel } \\
\text { 4 Presence of both electrical and } \\
\text { mechanical drive trains made } \\
\text { complex structure. } \\
\text { 5.Available commercially }\end{array}$ & $\begin{array}{l}\text { 1.Management of the } \\
\text { energy sources } \\
\text { 2.Battery and engine size } \\
\text { optimization }\end{array}$ \\
\hline FCEV & $\begin{array}{l}\text { 1.Electric } \\
\text { motor }\end{array}$ & $\begin{array}{l}\text { 1.Battery } \\
\text { 2.Fuel cell }\end{array}$ & $\begin{array}{l}\text { 1.Very little or no emission } \\
\text { 2. High efficiency } \\
\text { 3.Not dependent on supply of } \\
\text { electricity } \\
\text { 4.High price } \\
\text { 5. Available commercially }\end{array}$ & $\begin{array}{l}\text { 1.Cost of fuel cell } \\
\text { 2.Availability of fuelling } \\
\text { facilities }\end{array}$ \\
\hline PHEV & $\begin{array}{l}\text { 1.Electric } \\
\text { motor } \\
\text { 2.ICE }\end{array}$ & $\begin{array}{l}\text { As battery can be } \\
\text { recharged directly from the } \\
\text { grid, multiple power } \\
\text { sources can be used } \\
\text { 1.Battery } \\
\text { 2.ICE }\end{array}$ & $\begin{array}{l}\text { 1.Very little emission } \\
\text { 2.Long range } \\
3 \text { power from both electric supply } \\
\text { and fuel. } \\
\text { 4.More degrees of freedom to } \\
\text { supply the power demand }\end{array}$ & $\begin{array}{l}\text { 1.Management of the } \\
\text { energy sources } \\
\text { 2.Battery and engine size } \\
\text { optimization }\end{array}$ \\
\hline
\end{tabular}

Table -II : Comparison of different architectures of HEV: [4]

\begin{tabular}{|c|l|l|l|}
\hline SI.No & \multicolumn{1}{|c|}{ Type } & \multicolumn{1}{c|}{ Coupling used } & \multicolumn{1}{c|}{ Features } \\
\hline 1 & Series HEV & Electrical Coupling & Two electric powers are added. \\
\hline 2 & Parallel HEV & Mechanical Coupling & $\begin{array}{l}\text { Power from electric motor and ICE } \\
\text { are added together in a mechanical } \\
\text { coupler. }\end{array}$ \\
\hline
\end{tabular}




\begin{tabular}{|c|l|ll|l|}
\hline 3 & Series-parallel HEV & $\begin{array}{l}\text { Mechanical And Electrical } \\
\text { Coupling }\end{array}$ & $\begin{array}{l}\text { It combines the features of series } \\
\text { and parallel hybrid. } \\
\text { It has more operating modes. }\end{array}$ \\
\hline 4 & Complex HEV & $\begin{array}{l}\text { Mechanical And Electrical } \\
\text { Coupling }\end{array}$ & $\begin{array}{l}\text { It accommodates two power } \\
\text { converter and one mechanical } \\
\text { coupler. } \\
\text { It has complicated structure and } \\
\text { high cost. }\end{array}$ \\
\hline
\end{tabular}

\section{EXISTING EMS FOR HEVAND PHEV}

Based on the literature survey, energy management strategies are grouped in three categories such as in [22].
- $\quad$ Rule Based EMS

- Optimization Based EMS

- $\quad$ Learning-Based EMS

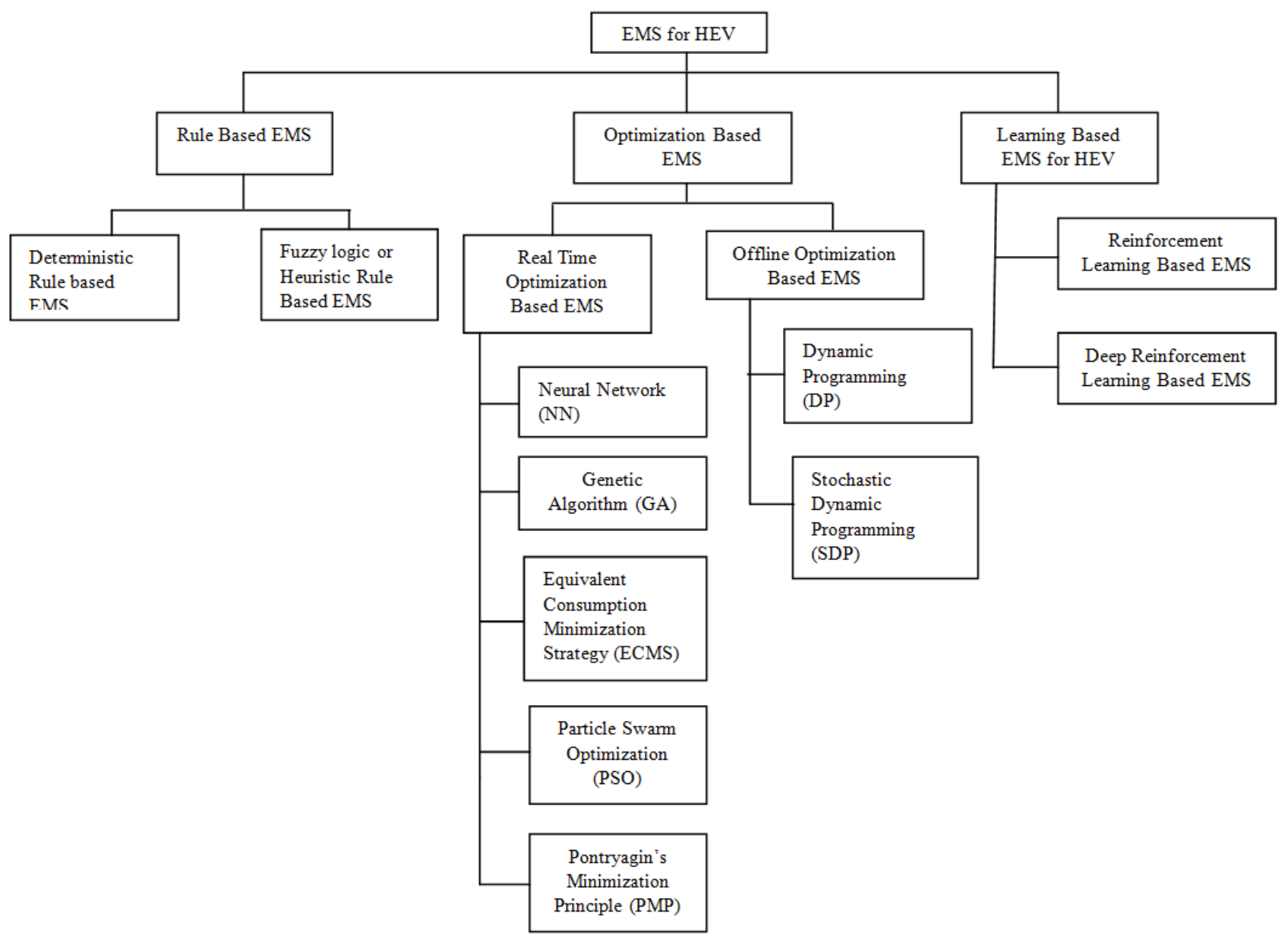

Fig.5. Different types of existing energy management strategies

\section{A. Rule-based EMS}

Rules are initially formed based on the assumption of future driving conditions and on desired outputs. And these rules can be deterministic rule-based and fuzzy logic rule-based [5].

\section{- Deterministic Rule-Based Methods}

Nashat Jalil et al. developed rule based EMS for series HEV [5].The researchers used thermostat and rule based energy management strategy. In thermostat, the status of SOC of battery is used to turn on the engine. In rule based power split, considering thermostat background and acceleration command ,power will be supplied by fuel engine or battery or combination of both.

Liu Shaohua et al. introduced rule based energy management strategy for Belt Driven Starter Generator in which all possible road load conditions are included to form rules for energy management strategy [6]. Harpreetsingh Banvait et al. proposed energy management 
strategy for plug in hybrid electric vehicle (PHEV) [7]. In all these rule based method, rules are clearly defined for power split by battery and Fuel engine but these methods fail to work under situations faced by vehicles non linear driving conditions.

\section{- Fuzzy logic or Heuristic Rule based EMS}

Fuzzy logic controllers are rule-based systems which use linguistic variables and simple rules to imitate the human reasoning process. As fuzzy rule-based approach does not require precise mathematical models of the controlled system, they are particularly useful when applied to complex multi-domain system nonlinear, time-varying systems like HEV [9].

The researchers presented fuzzy logic control of EMS for parallel HEV [8],[10]. Here fuzzy membership function is assigned for SOC of battery and the difference between the torque required by vehicle and the torque provided by engine. The disadvantage of these methods is the requirement of expert knowledge which must involve in the process of fuzzification and defuzzification used for decision making.

\section{B. Optimization Based EMS}

Various optimization based EMS have been studied in this paper for energy management strategies in $\mathrm{HEV}$ [12]-[20].

Using maximum power search algorithm, engine operating points based on efficiency map of engine and generator, efficiency of battery is found out. This ensures optimal energy delivered by hybrid sources to drive system. But the overall engine efficiency is $1-2 \%$ less than equivalent consumption minimization strategy (ECMS) [12].

Some of the vehicles like city bus follow same driving cycle, the optimization method using deterministic dynamic programming (DDP) approach can be used to obtain global optimal solutions. Optimization algorithm based on the knowledge of the efficiency maps of the internal combustion engine (ICE) and the generator for the energy management system in hybrid electric vehicles requires a full knowledge of the driving cycle condition and is not suitable for real time applications due to its computational intensity [13].

Some of the intelligent management systems such as neural networks, fuzzy logic, Genetic algorithm and Particle Swarm Optimization are combined with global optimization methods to provide real time solutions for energy ratio split between battery and engine[14],[15].

Shaobo Xie et al. developed an Adaptive Equivalent Consumption Minimum (A-ECMS) Strategy for a Plugin Hybrid Electric vehicle. But this method is proposed for only fixed route [16].These optimization methods do not offer an on-line solution and also the assumptions made here is the future driving cycle is known.

\section{Learning-based EMS}

Previously discussed EMS strategies are just follow predefined rules or assumption of future driving conditions which are not adaptive to dynamic driving conditions. In this study, a reinforcement learning based $\mathrm{HEV}$ energy management system is reviewed to autonomously learn the optimal fuel use from its own historical driving record. It does not rely on any prediction or predefined rules. Different learning based energy management strategies that are existing are discussed in this paper [21]-[26].

- Reinforcement Learning

- Deep Reinforcement Learning

Teng Liu et al. proposed two reinforcement learning namely $Q$-learning and Dyna algorithms. The fuel consumption is same and the computational cost is less than the dynamic programming [21].

The model proposed by Xuewei Qi et al. combines a Qlearning, a value based learning algorithm and a deep neural network to form a deep Q-network which is capable of learning and providing the optimal solution in continuous environment [22]. RuiXionga et al used the RL-based online strategy to reduce total energy loss due to temperatures, states of health, initial SOCs and driving cycles and improve the system efficiency under different conditions [23].

Deep neural network with Q learning proposed by Jingda $\mathrm{Wu}$ et al. in which the fuel economy of proposed DQL-based strategy gets a $5.6 \%$ better performance than Q learning [24].

\section{COMPARISON OF EMSS IN TERMS OF FUEL CONSUMPTION}

Based on the analysis, among all energy management strategies, learning based EMS are preferred over rule based and optimization based EMS [25],[27].Driving range and SOC offered by learning Based EMS is also more [25],[28].Fuel consumption for various energy management strategies is listed in Table-III and the same shown in Fig.6. From Table-III, fuel consumption decreases by $8.3 \%$ using Rule Based EMS and 10.1\% using Learning Based EMS.SOC profile for Rule Based, Charge Depleting-Charge Sustaining (CD-CS) mode, Optimization Based is shown in Fig.7.

Table -III: Comparison of different EMSs in terms of fuel consumption

\begin{tabular}{|c|c|c|}
\hline Sl.No & $\begin{array}{c}\text { Energy Management } \\
\text { Strategy (EMS) }\end{array}$ & $\begin{array}{c}\text { Fuel Consumption } \\
(\mathbf{L} / \mathbf{1 0 0} \mathbf{~ k m})\end{array}$ \\
\hline 1. & Rule-Based EMS & 3.857 \\
\hline 2. & $\begin{array}{c}\text { Optimization Based } \\
\text { EMS (Dynamic } \\
\text { programming) }\end{array}$ & 3.537 \\
\hline 3. & $\begin{array}{c}\text { Learning-Based EMS } \\
\text { (Deep Reinforcement } \\
\text { Learning Based) }\end{array}$ \\
\hline
\end{tabular}




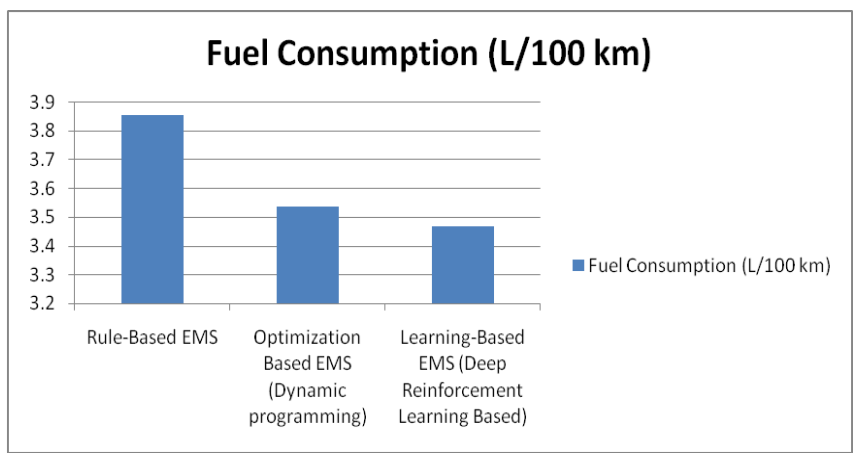

Fig.6. Fuel consumption using various EMS

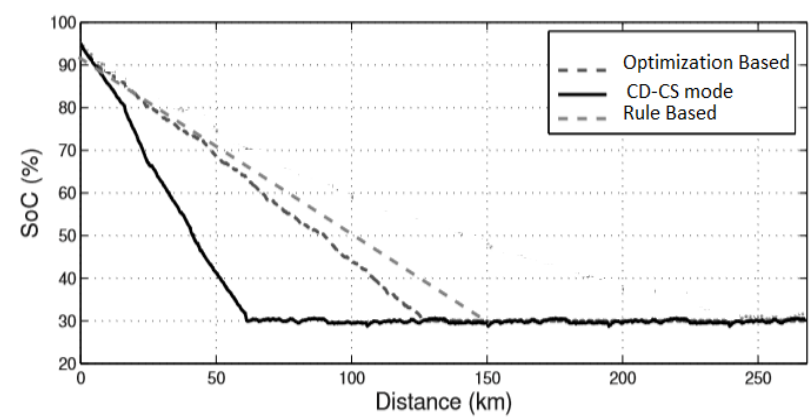

Fig.7. SOC profile

\section{CONCLUSION}

This paper focuses on analysis on classification of electric vehicles and different energy management strategies. Among different types of electric vehicles, due to long range drivability and lower emission, PHEV is preferred. This also provides room for vehicle to grid and vehicle to home power transfer. Based on the analysis on various existing energy management strategies for HEV and PHEV, Learning Based EMS is preferred. Still to get better vehicle performance, combination of EMS can be carried out as the driving cycles are not predictable.

\section{REFERENCES}

1. Chan, C.C., "The state of the art of electric and hybrid vehicles,". Proc. IEEE 2002, 90, 247-275.

2. Martinez, C.M.; Hu, X.; Cao, D.; Velenis, E.; Gao, B.; Wellers, M., "Energy Management in Plug-in Hybrid Electric Vehicles: Recent Progress and a Connected Vehicles Perspective,". IEEE Trans. Veh. Technol. 2017, 66, 4534-4549

3. L. Guzzella and A. Sciarretta, Vehicle Propulsion Systems,. vol. 1. Berlin, Germany: Springer-Verlag, 2007

4. Mehrdad Eshani , "Modern Electric, Hybrid Electric and Fuel Cell Vehicles ,Fundamentals, Theory and Design,” by , yiminGao, AliEmadi CRC press 2010 by Taylor and Francis Group, LLC.

5. N. Jalil, N. A. Kheir, and M. Salman, "A rule-based energy management strategy for a series hybrid vehicle," in Proc. Amer. Control Conf., Albuquerque, NM, Jun. 1997, vol. 1, pp. 689-693.

6. S. Liu, C. Du, F. Yan, 1. Wang, Z. Li and Y. Luo, "A Rule-based Energy Management Strategy for a New BSG Hybrid Electric Vehicle, " IEEE Third Global Congress on Intelligent Systems, 978-0-76954860-9/12, 2012.

7. H. Banvait, S. Sohel, and Y. Chen, "A rule-based energy management strategy for plug-in hybrid electric vehicle (PHEV)," in Proc. Amer. Control Conf., St. Louis, MO, Jun. 2009, pp. 3938-3943.

8. D. Lu, W. Li, G. Xu, and M. Zhou, "Fuzzy logic control approach to the energy management of parallel hybrid electric vehicles," in Proceedings of the IEEE International Conference on Information and Automation (ICIA '12), pp. 592-596, Shenyang, China, June 2012.

9. D Smith, R Douglas, W Naeem , "Fuzzy Rule-Based Energy Management Strategy for a Parallel Mild-Hybrid Electric Bus,' IEEE
International Conference on Electrical Systems for Aircraft, Railway, Ship Propulsion and Road Vehicles \& International Transportation Electrification Conference (ESARS-ITEC)- November 2018.

10. W Wang, F Qu, Q Wang, C Wu , "Research on Energy Control Strategy of 4WD Hybrid Electric Vehicle Based on Fuzzy Control," 2nd IEEE Advanced Information Management, Communicates, Electronic and Automation Control Conference (IMCEC) May 2018.

11. Sabri MF, Danapalasingam KA, Rahmat MF, "A review on hybrid electric vehicles architecture and energy management strategies,". Renew.Sustain. Energy Rev.2016;53:1433-42.

12. Sabri MF, Danapalasingam KA, Rahmat MF. A review on hybrid electric vehicles architecture and energy management strategies. Renew.Sustain. Energy Rev.2016;53:1433-42.

13. Gokce, K.; Ozdemir, A, “An instantaneous optimization strategy based on efficiency maps for internal combustion engine/battery hybrid vehicles,”. Energy Convers. Manag. 2014, 81, 255-269.

14. Odeim, F.; Roes, J.;Wulbeck, L.; Heinzel, A, "Power management optimization of fuel cell/battery hybrid vehicles with experimental validation,”. J. Power Sources 2014, 252, 333-343.

15. ChenZ, MiCC, Xu J, "Member Energy management for a power-split plug-in hybrid electric vehicle based on dynamic programming and neural networks,". IEEE TransVehTechnol2014;63:1567-80.

16. Chen, Z.; Mi, C.C.; Xiong, R.; Xu, J.; You, C, “ Energy management of a power-split plug-in hybrid electric vehicle based on genetic algorithm and quadratic programming,”. J. Power Sources 2014, 248, 416-426.

17. C. Shen and X. Chaoying, "Optimal power split in a hybrid electric vehicle using improved dynamic programming," in Proceedings of the Asia-Pacific Power and Energy Engineering Conference (APPEEC '10), pp. 1-4,Chengdu,China,March 2010.

18. Xie, S.; Li, H.; Xin, Z.; Liu, T.; Wei, L, "A pontryagin minimum principle-based adaptive equivalent consumption minimum strategy for a plug-in hybrid electric bus on a fixed route,". Energies 2017, 10, 1379.

19. P. Tulpule, V.Marano, and G. Rizzoni, "Energy management for plugin hybrid electric vehicles using equivalent consumption minimisation strategy," International Journal of Electric and Hybrid Vehicles, vol. 2, no. 4, pp. 329-350, 2010.

20. Vagg, C.; Akehurst, S.; Brace, C.J.; Ash, L., "Stochastic dynamic programming in the real-world control of hybrid electric vehicle". IEEE Trans. Contr. Syst. Techol. 2016, 24, 853-866.

21. Teng Liu, Yuan Zou, ,Dexing Liu and Fengchun Sun, "Reinforcemen Learning-Based Energy Management Strategy for a Hybrid Electric Tracked Vehicle,".. Energies 2015, 8, 7243-7260.

22. Qi, X.; Luo, Y.;Wu, G.; Boriboonsomsin, K.; Brath, M.J, "Deep reinforcement learning-based vehicle energy efficiency autonomous learning system,". In Proceedings of the 2017 IEEE Intelligent Vehicles Symposium (IV),Redondo, Beach, CA, USA, 11-14 June 2017.

23. Xiong R, Cao J, Yu Q, "Reinforcement learning-based real-time power management for hybrid energy storage system in the plug-in hybrid electric vehicle,". Appl Energy 2018;211:538-48.

24. Wu J, He H, Peng J, Li Y, Li Z, “ Continuous reinforcement learning of energy management with deep Q network for a power split hybrid electric bus,”. Appl. Energy 2018;222:799-811.

25. Yue Hu, Weimin Li, Kun Xu, TaimoorZahid, Feiyan Qin ,Chenming $\mathrm{Li}$, " Energy Management Strategy for a Hybrid Electric Vehicle Based on Deep Reinforcement Learning,”. Appl. Sci. 2018, 8, 187;

26. Yuankai $\mathrm{Wu}$, HuachunTanb, JiankunPenga, HailongZhangb, HongwenHea , "Deep reinforcement learning of energy management with continuous control strategy and traffic information for a seriesparallel plug-in hybrid electric bus,".. Appl Energy 2019;247:454-466.

27. Feiyan Qin , Guoqing $\mathrm{Xu}$, Yue Hu, Kun Xu and Weimin $\mathrm{Li}$, “ Stochastic Optimal Control of Parallel Hybrid Electric Vehicles," Energies 2017, 10, 214

28. Laura Tribiolia, Michele Barbierib, Roberto Capatac, Enrico Sciubbac, Elio Jannellid, Gino Bellab , "A real time energy management strategy for plug-in hybrid electric vehicles based on optimal control theory," Energy Procedia 45 ( 2014 ) 949 - 958 


\section{AUTHORS PROFILE}

S.Karkuzhali is Assistant Professor in Electrical and Electronics Engineering Department, R.M.D Engineering College, Chennai, India. She received her B.E. degree in Electrical \& Electronics Engineering from the Pallavan Engineering College,Kancheepuram, India, M.E. degree in Power Electronics and Drives from Mepco Schlenk Engineering College, Sivakasi, India. She has published two technical papers in international and national conferences. She has 11 years of teaching experience. Her earlier industrial experience 3 years with HCL Technologies Ltd., Chennai, India. Her research interests on Hybrid Electric Vehicle. She is a Life member of Indian Society for Technical Education.

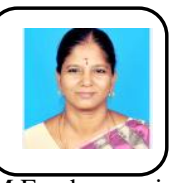

P.Usha Rani is Professor in Electrical and Electronics Engineering Department, R.M.D Engineering College, Chennai, India. She received her B.E. degree in Electrical \& Electronics Engineering from the Government College of Technology, Coimbatore, India, M.E. degree in Power Systems from College of Engineering, Anna University, Chennai, India and Ph.D in the area of Power Electronics and Drives from Anna University, Chennai, India. She has published over 57 technical papers in international and national journals / conferences proceedings (IEEE Xplore-7). She has 22 1/2 years of teaching experience. Her earlier industrial experience 4 years was with Chemin Controls, Pondicherry, India. Her research interests on application of power electronics to power quality problems and FACTS. She is a Senior member of IEEE and Life member of Indian Society for Technical Education. 